\title{
A Survey on Marketing Potential of Maize Seed Production in the Western Hill of Nepal
}

\author{
Kiran R. Joshi \\ Agriculture Research Station-NARC, Lumle
}

\begin{abstract}
A Marketing Rural Rapid Appraisal Survey (MRRA) was conducted from 12-16 June 2002 in Bhakimli (1725 masl), Myagdi district. Two factors namely gender (male and female) and wealth category rich, medium and poor were considered in accessible area of Bhakimli. Semi-structured questionnaires and checklist were used to collect information on maize seed production, marketing opportunities and marketing system for producers, traders and consumers. The objectives of the study were to understand existing maize seed production, demand and supply; to identify the problems associated with the seed marketing system and policy options for sustainable maize seed production. Farmers groups in Bhakimli were involved in maize seed production and management of marketing. Successful seed production for long-term would ensure a continuous supply of open pollinated variety (OPV) seed in farmers' level. Seed production as a new commercial enterprise created employment opportunities as well as income generating in the Western hills of Nepal.
\end{abstract}

Keywords: Commercial enterprises, community seed production, employment, income generating, marketing potential

\section{INTRODUCTION}

Maize is the second important crop in Nepal. It is a staple crop of the hill people that occupies 825000 ha and contributes $78.3 \%$ to the total maize production $(14,84,112$ ton) in the country (MOAC 2001). Nearly $69 \%$ of the maize area in the hills is under local varieties. An improved variety has higher productivity over local by $42 \%$ and $39 \%$ in the high hills and hills, respectively (MOAC 2001). Although a number of composite varieties have been released for cultivation, their larger spread is impeded by non-accessibility of seeds to the farmers. In Myagdi district, maize occupies 8750 hectare of land with the production of 14350 ton (MOAC 2001). Increasing the access to improved maize seeds for farmers can be an important step towards increasing productivity of maize in the farmer's field. Marketing research on seed is the systematic gathering of information concerning the consumers' need, buying habits and availability of seed for farmers (LARC 1997). A study conducted in Nepal (Seeley 1998) revealed that farmers using regulated OPV seeds noticed significant changes in maize plant and it was stressed that there is a need to develop a long term strategy that would ensure continuing supply of open pollinated variety (OPV) seeds. Initially, Agriculture Research Station, Lumle provided inputs like fertilisers and foundation maize seed as well as seed production training to each community group. Community managed on farm maize seed production program was implemented in Bhakimli, which helped toward establishing a new enterprise for employment, income generation (Joshi et al 2002). In the western hills of Myagdi district, seed production has been initiated jointly by the Agricultural Research Station Lumle, Agricultural Development Office (Myagdi) and Seed Sector Support Project as a partnership program.

\section{METHODOLOGY}

A survey on identification of marketing potential of maize seed production was conducted from 12-16 June 2002 at accessible area of Bhakimli ward No 5 of Myagdi district, MRRA was the basic technique 
applied. Semi-structured questionnaire was developed for marketing survey. A total of twenty-two questions in relation to seed production systems, supply and demand were considered and asked to the concerned farmers of the village at maize cultivated area for improved and local maize during 2001 and 2002. The questionnaire survey covered 15 farmers 5 in each of three categories viz. farmers with food sufficiency for more than 12 months (A), for 6-12 months (B) and less than 6 months (C). The questionnaire raised to households was both male headed and female headed. After completion of field survey, group discussion was held with farmers, who managed community maize seed production and faced some problems of marketing system of maize associated with improved and local maize seed production. Secondary data was also collected from ADO, Myagdi, SSSP, Beni and Agrovet centres of Beni and Pokhara.

\section{RESULTS AND DISSCUSSION}

In the survey area, farmers were growing maize and finger millet as relay crop in Bari land. Maize growing period is March - August and millet growing period is July - November. Farmers in category A had total cultivated (Khet and Bari land) of 1.18 ha, farmers of category B had 0.46 ha and farmers of category $\mathrm{C}$ had 0.26 ha. Total maize cultivated area of category A was higher (0.62 ha.) as compared to category B (0.35 ha) and category C (0.22 ha). Farmers grow improved varieties such as Manakamana 3, White hill pool, Yellow hill pool and Rampur Composite and local maize were Seto Makai, Pahenlo Makai and Khairo Makai. Category A produced maize grain yield of $3.2 \mathrm{t} / \mathrm{ha}$, category B produced 3.5 $\mathrm{t} / \mathrm{ha}$ and category $\mathrm{C}$ produced $3.7 \mathrm{t} / \mathrm{ha}$ in Bari land of Bhakimli in 2001/2002. Table 1 shows a pattern of land use in survey site.

Table 1. Existing maize production system at accessible Bhakimli ward No. 5 area, western hill, Myagdi district, 2001/02

\begin{tabular}{|c|c|c|c|c|c|c|c|c|c|c|}
\hline \multirow[t]{2}{*}{$\mathrm{SN}$} & \multirow[t]{2}{*}{ Farmers categories } & \multicolumn{2}{|c|}{ A, Mean } & \multirow{2}{*}{$\begin{array}{r}\text { Total } \\
\text { area, ha }\end{array}$} & \multicolumn{2}{|c|}{ B, Mean } & \multirow{2}{*}{$\begin{array}{r}\text { Total } \\
\text { area, ha }\end{array}$} & \multicolumn{2}{|c|}{ C, Mean } & \multirow{2}{*}{$\begin{array}{r}\text { Total } \\
\text { area, ha }\end{array}$} \\
\hline & & Khet & Bari & & Khet & Bari & & Khet & Bari & \\
\hline 1 & Cultivated area, ha & 0.62 & 0.56 & 1.18 & 0.19 & 0.27 & 0.46 & 0.10 & 0.16 & 0.26 \\
\hline 2 & Maize cultivated area, ha & 0.16 & 0.46 & 0.62 & 0.10 & 0.25 & 0.35 & 0.08 & 0.14 & 0.22 \\
\hline \multirow[t]{3}{*}{3} & Maize covered area, ha & & & & & & & & & \\
\hline & A) Improved & 0.16 & 0.45 & 0.61 & 0.01 & 0.24 & 0.25 & 0.03 & 0.11 & 0.14 \\
\hline & B) Local & 0.00 & 0.01 & 0.01 & 0.09 & 0.01 & 0.10 & 0.05 & 0.03 & 0.08 \\
\hline \multirow[t]{3}{*}{4} & Maize production (improved), $\mathrm{t} / \mathrm{ha}$ & & & & & & & & & \\
\hline & $2000 / 01$ & - & 3.0 & 3.0 & - & 3.5 & 3.5 & - & 3.5 & 3.5 \\
\hline & $2001 / 02$ & - & 3.2 & 3.2 & - & 3.5 & 3.5 & - & 3.7 & 3.7 \\
\hline
\end{tabular}

There is opportunity for maize seed production in Western hills of Nepal. Community based maize seed production program has been started from 2000/2001 in Bhakimli, Myagdi. Farmers' categories A, B and C require seed of $14.0 \mathrm{~kg}$ for $0.46 \mathrm{ha}, 7.3 \mathrm{~kg}$ for 0.25 .ha and $6.0 \mathrm{~kg}$ for 0.14 ha respectively. Category A, B and $\mathrm{C}$ produced $484.0 \mathrm{~kg}, 280.0 \mathrm{~kg}$ and $170.0 \mathrm{~kg}$ maize seed respectively for selling purposes to different agencies. Improved seed demand from the neighbour was about $12.2 \mathrm{~kg}$ for $0.46 \mathrm{ha}$. Similarly, farmers households categories of $\mathrm{A}, \mathrm{B}$ and $\mathrm{C}$ in total required 12.4 for $0.54 \mathrm{ha}, 7.5 \mathrm{~kg}$ for 0.33 ha and $4.2 \mathrm{~kg}$ for 0.20 ha respectively. It was found that Bhakimli farmers' demand for improved maize seed was very low (Table 2).

Out of the total amount of seed sold to different agencies, ARS, Lumle purchased $1000 \mathrm{~kg}$ of Manakamana 3,500 kg of White hill pool and $500 \mathrm{~kg}$ of Arun 1 from community based seed of $3.05 \mathrm{ha}$ produced at Bhakimli and Dhudhekhola from 17 farmers. Remaining maize seed was exchanged with neighbour farmers as barter system. Community based farmers group sold their maize seed to different agrovets and agencies. 33\% of the total cost included for seed sheller, drying, storage losses, grading and transportation cost is only Rs $1-1.50 / \mathrm{kg}$ for (Beni) market. The cost of maize seed was Rs 11.60/kg in Myagdi. 
Table 2. Opportunities of maize seed production demand and supply system of Bhakimli area, western hill, Myagdi district, 2001/02

\begin{tabular}{|c|c|c|c|c|}
\hline SN & Farmers categories & A, Mean & B, Mean & C, Mean \\
\hline \multirow[t]{3}{*}{1} & Maize varietal grown by farmers, ha & & & \\
\hline & a) Improved & 0.46 & 0.25 & 0.14 \\
\hline & b) Local & - & - & - \\
\hline 2 & Total house hold seed required, $\mathrm{kg}$ & 14.0 & 7.3 & 6.0 \\
\hline 3 & Local price for improved maize seed, $\mathrm{kg}$ & 17.6 & 19.4 & 19.0 \\
\hline 4 & Local price of maize grain for home consumption, $\mathrm{kg}$ & 10.0 & 10.5 & 10.5 \\
\hline 4 & Maize seed required for cultivation, $\mathrm{kg}$ & 246.0 & 142.0 & 114.0 \\
\hline 5 & Maize seed sell, $\mathrm{kg}$ & 484 & 280 & 170 \\
\hline 6 & Source of seed & ARS, Lumle & ARS, Lumle & ARS, Lumle \\
\hline \multirow[t]{5}{*}{7} & Utilization of selected source seed for different area, ha & & & \\
\hline & a) From selected grain before planting, ha & 0.37 & 0.24 & 0.10 \\
\hline & b) Ear selection at planting, ha & 0.07 & 0.03 & 0.15 \\
\hline & c) Selected ears from the field and store separately, ha & 0.18 & 0.06 & 0.13 \\
\hline & d) Obtain from neighbours, ha & 0.03 & - & - \\
\hline 8 & Seed demand from neighbours, $\mathrm{kg}$ & 12.2 & 5.75 & 3.5 \\
\hline 9 & Membership of community based managed seed production & Yes & Yes & Yes \\
\hline
\end{tabular}

Agrovets purchased maize seed @ Rs 18/kg from the seed growers and sell at retail price of about Rs. $26-28 / \mathrm{kg}$. Generally, agrovets received marginal profit of Rs. 7-8/kg. However, ARS, Lumle was adding $25 \%$ cost for seed losses, seed treatment and transportation cost. Seed Support Sector Project is however subsidizing these extra costs to the farmers and selling seed at prices actually bought (Table 3).

Table 3. Marketing of maize seed enterprises for different institutions, 2001/02

\begin{tabular}{llrrrrr}
\hline SN & Particular & \multicolumn{4}{c}{ Agencies/Institutions } \\
\cline { 3 - 6 } & & ARS, Lumle & ADO, Myagdi & SSSP & \multicolumn{2}{c}{ Agrovet } \\
& & & & & Beni & Pokhra \\
\hline 1 & Amount of seed sold to different agencies, kg & & 500 & 500 & 82 & 100 \\
& a) Manakamana -1 & 5000 & 500 & 275 & 27 & 50 \\
& b) Arun-1 & 500 & 250 & 100 & 10 & 50 \\
c) White hill pool & - & 7.63 & - & - & - \\
& Cost of production of maize, Rs/kg & - & $11.60 *$ & - & - & - \\
& Cost of maize seed production, Rs/kg & 18 & 18 & 18 & 18 & 18 \\
2 & Buying price, Rs/kg & 23 & 23 & 18 & 25 & 26 \\
3 & Selling price, Rs/kg & 5 & 5 & 0 & 7 & 8 \\
4 & Marginal profit & & & & \\
\hline
\end{tabular}

It takes $8 \mathrm{hrs}$ for the farmers to go up and down and finally reached at central market of Beni for marketing purpose. Group discussion was held with community based maize seed/grain producers. Indicated that lack of high yielding varieties was a major problem (rank 1), followed by storage pest and lack of storage structure for seed grain problems (ranked second and third) (Table 4).

In terms of problems of marketing system, it was indicated that lack of awareness in selecting the quality seed and availability of poor quality seed ranked as numbers one problem. Lack of proper marketing system and information on marketing system ranked second and third problems respectively (Table 5).

Figures for marketing function at different levels indicate that grain prices in the local markets were less than in the near by markets. The average grain price at local level was Rs $12 / \mathrm{kg}$ and the average seed price was Rs $26 / \mathrm{kg}$ in nearby market. Retail prices were reported at marginal profit of Rs 2-8. Majority of the farmers preferred to sell seed in Beni Bazar (market) and Baglung Bazar. Seed Sector Support Project (SSSP) is playing vital role as a mediator for seed marketing mechanism as well as it coordinates between seed producer groups and traders (Figure 1). 
Table 4. Problems of improved maize seed growers at accessible area, Bhakimli VDC (martix ranking), 2001/02

\begin{tabular}{llrrrrrrrrrrr}
\hline SN & Indicator & 1 & 2 & 3 & 4 & 5 & 6 & 7 & 8 & 9 & Total & Rank \\
\hline 1 & Lack of high yielding varieties & $\mathrm{X}$ & 1 & 1 & 1 & 1 & 1 & 1 & 1 & 1 & & 8 \\
2 & Non effective group mobilization & $\mathrm{X}$ & $\mathrm{X}$ & 3 & 4 & 5 & 6 & 7 & 8 & 9 & 0 & 6 \\
3 & Timely unavailability of input (chemical fertilizer) & $\mathrm{X}$ & $\mathrm{X}$ & $\mathrm{X}$ & 4 & 5 & 6 & 7 & 8 & 9 & 1 & 5 \\
4 & Pest problem (army worm and white grub) & $\mathrm{X}$ & $\mathrm{X}$ & $\mathrm{X}$ & $\mathrm{X}$ & 5 & 6 & 7 & 4 & 9 & 3 & 4 \\
5 & Disease problem (cob smut and head smut) & $\mathrm{X}$ & $\mathrm{X}$ & $\mathrm{X}$ & $\mathrm{X}$ & $\mathrm{X}$ & 6 & 7 & 8 & 9 & 3 & 4 \\
6 & Tarpaulin for seed drying & $\mathrm{X}$ & $\mathrm{X}$ & $\mathrm{X}$ & $\mathrm{X}$ & $\mathrm{X}$ & $\mathrm{X}$ & 7 & 8 & 6 & 5 & 3 \\
7 & Lack of storage structure for seed/rain & $\mathrm{X}$ & $\mathrm{X}$ & $\mathrm{X}$ & $\mathrm{X}$ & $\mathrm{X}$ & $\mathrm{X}$ & $\mathrm{X}$ & 8 & 9 & 5 & 3 \\
8 & Lack of corn sheller & $\mathrm{X}$ & $\mathrm{X}$ & $\mathrm{X}$ & $\mathrm{X}$ & $\mathrm{X}$ & $\mathrm{X}$ & $\mathrm{X}$ & $\mathrm{X}$ & 9 & 5 & 3 \\
9 & Storage pest problems (weevil and moth) & $\mathrm{X}$ & $\mathrm{X}$ & $\mathrm{X}$ & $\mathrm{X}$ & $\mathrm{X}$ & $\mathrm{X}$ & $\mathrm{X}$ & $\mathrm{X}$ & $\mathrm{X}$ & 6 & 2 \\
\hline
\end{tabular}

Table 5. Problems of marketing system of maize seed production at accessible area, Bhakimli VDC (matrix ranking), 2001/02

\begin{tabular}{|c|c|c|c|c|c|c|c|c|c|c|c|}
\hline SN & Indicator & 1 & 2 & 3 & 4 & 5 & 6 & 7 & 8 & Total & Ranking \\
\hline 1 & Lack of proper marketing system & $\mathrm{X}$ & 1 & 3 & 4 & 5 & 6 & 7 & 8 & 1 & 3 \\
\hline 2 & Transportation problem for seed & $\mathrm{X}$ & $\mathrm{X}$ & 3 & 4 & 5 & 6 & 7 & 8 & 0 & 4 \\
\hline 3 & Lack of seed traders & $X$ & $\mathrm{X}$ & $\mathrm{X}$ & 4 & 5 & 3 & 7 & 8 & 3 & \\
\hline 4 & Lack of support price for seed pro & $\mathrm{X}$ & $\mathrm{X}$ & $\mathrm{X}$ & $\mathrm{X}$ & 5 & 6 & 7 & 8 & 3 & \\
\hline 5 & Seed storage problem & $\mathrm{X}$ & $\mathrm{X}$ & $\mathrm{X}$ & $\mathrm{X}$ & $\mathrm{X}$ & 5 & 7 & 5 & 6 & \\
\hline 6 & information on $\mathrm{ma}$ & $\mathrm{X}$ & $\mathrm{X}$ & $\mathrm{X}$ & $\mathrm{X}$ & $\mathrm{X}$ & $\mathrm{X}$ & 7 & 8 & 3 & \\
\hline 7 & or qu & $\mathrm{X}$ & $\mathrm{X}$ & $\mathrm{X}$ & $\mathrm{X}$ & $\mathrm{X}$ & $\mathrm{X}$ & $\mathrm{X}$ & 8 & 6 & \\
\hline 8 & Lack of awareness in selecting the quality s & $X$ & $\mathrm{X}$ & $\mathrm{X}$ & $\mathrm{X}$ & $\mathrm{X}$ & $\mathrm{X}$ & $\mathrm{X}$ & $\mathrm{X}$ & 6 & \\
\hline
\end{tabular}

Problem of lack of markets: Markets for maize seed are very thinly spread. Due to inadequately developed markets for maize, farmers usually received less prices in the local (village) markets than in the organized markets, which were located at some distance from the village. The loss due to lack of maize market in village is computed as follow:

$$
\begin{aligned}
\mathrm{Lm} & =\left\{\left(\mathrm{PRM}_{\mathrm{m}}-\mathrm{PRM}_{\mathrm{v}}\right)-\mathrm{TC}_{\mathrm{m} \cdot \mathrm{v}}\right\} * \mathrm{MQV} \\
& =\{(18-14)-1.50\} * 500 \\
& =\{4-1.50\} * 500 \\
& =2.50 * 500=1250
\end{aligned}
$$

Where, $\mathrm{Lm}$ is the loss due to lack of market in the village, PRMm is the price received by the farmers in the approachable near by market; PRMv is the price received by the farmers in the village; TCm.v is the transportation cost differential between organized market and MQV is the quantity of maize sold in the village (Joshi and Sing 2001). The local market price of maize seed was Rs 14.0 at Bhakimli and Rs 18.0 at Beni. Transportation cost from Bhakimli to Beni market was Rs 1.50/kg. The farmers of Bhakimili can obtain at least NRs $1.50 / \mathrm{kg}$ seed if sold to the retailers at NRs $17.00 / \mathrm{kg}$ at Beni. So, market of Beni is less profitable for farmers of Bhakimli. 
Figure 1. Marketing system of community based maize seed growers.

\section{CONCLUSION}

Farmers are more demanding high yielding variety of maize seed. Community based maize seed production program should be implemented in inaccessible areas and minimum support price should be announced for maize seed/grain growers before planting season. Agricultural Development Bank should provide loan at minimum interest rate for community based seed producers in inaccessible or remote areas of hills. Researchers and extensionists should conduct combine training on post harvest technologies for seed growers. Agricultural Development Offices, NGOs/INGOs should explore marketing enterprises.

\section{ACKNOWLEDGEMENTS}

I wish to express their gratitude to Dr RP Sah, Station chief, ARS, and Lumle for his encouragement in implementing this study project successfully. The authors are pleased to acknowledge the considerable technical and financial support of Dr Joel Ransom, Dr N Rajbhandari, Dr K Paudyal and Dr TP Tiwari and staff members of CIMMYT, Kathmandu and support staff members of ARS, Lumle. Collaboration of District Agricultural Development Office, Myagdi is highly acknowledged. The authors are also thankful to the staff members of Seed Sector Support Project, District Office, Myagdi for their valuable co-operation in implementing the study project. 


\section{REFERENCES}

Joshi KR, TB Karki and S Paudel. 2002. Community managed maize seed production program. An experience of ARS, Lumle. LARC Working Paper No. 2002/03. ARS, Lumle, Kaski..

Joshi PK and NP Sing. 2001. Intensification of maize production in upland area of India, prioritisation for research and development plans. The paper presented in the $4^{\text {th }}$ workshop held from 4-8 June at Kathmandu.

LARC. 1997. The strategy for maize research. LARC Strategy Paper No. 97/7. Lumle Agricultural Research Center, Kaski.

MOAC. 2001. Statistical information on Nepalese agriculture-2000/2001. Agribusiness Promotion and Statistical Information Division, Ministry of Agriculture and Cooperatives. HMG/N, Singha Durbar, Kathmandu, Nepal.

Seeley J. 1998. Household maize variety selection in Lumle Agricultural Centre extension command area. LARC Technical Paper No. 88/24. ARS, Lumle, Kaski. 